\title{
Estimation of Horizontal Fluxes of Submicron Atmospheric Aerosol in the Middle Urals
}

\author{
E.S. Nagovitsyna ${ }^{1,2, a)}$, V.A. Poddubny ${ }^{1, \text { b) }}$, A.P. Luzhetskaya ${ }^{1, c)}$ \\ ${ }^{1}$ Institute of Industrial Ecology of the Ural Branch of the Russian Academy of Sciences, S. Kovalevskaya 20, \\ Ekaterinburg, Russia, 620990 \\ ${ }^{2}$ Ural Federal University, Mira 19, Ekaterinburg, Russia, 620002 \\ ${ }^{a)}$ Corresponding author: ekaterinan@ecko.uran.ru \\ b)Vassily.Poddubny@gmail.com \\ c)ann@ecko.uran.ru
}

\begin{abstract}
The results of the estimation of submicron atmospheric aerosol horizontal fluxes by the method of Fluid Location of the Atmosphere (FLA) are presented. For this purpose, the three-dimensional problem of reconstructing the spatial structure of the aerosol distribution taking into account wet and dry deposition of aerosol particles on the underlying surface is solved numerically. The initial data were the results of photometric measurements during 2016 on the Middle Urals.

Keywords: Fluid Location of the Atmosphere, atmospheric aerosol, photometric measurements.
\end{abstract}

\section{METHOD}

The task of estimating the spatial structure of an aerosol concentration field by the FLA method is performed in three stages [1-3].

1. Statistical estimate of the average concentration field. At this stage, the average field of the measured parameter $\varphi$ (such as pollutant concentration) is estimated on the basis of the Seibert method [4].

2. Euler stage. The average concentration field and the field of air motion velocities $\vec{v}$ are used to estimate the fields of sources/sinks; this is done using a conservation equation for the analyzed (instrument-measured) $\varphi$ parameter in the Euler representation.

3. The Lagrange stage. The estimate of the source power field is used to calculate the distribution of the measured characteristic along each trajectory of motion of the Lagrange particle with the help of a conservation equation in the corresponding form.

As a result, it becomes possible to estimate the average flux $\bar{F}_{l}$ of a submicron atmospheric aerosol passing through a given vertical plane according to the formula:

$$
\overline{F_{l}}=\overline{(v \varphi)_{l}}=\bar{v}_{l} \bar{\varphi}_{l}+\overline{v_{l, k}^{\prime} \varphi_{l, k}^{\prime}}
$$

where, $\bar{v}_{l}$ - average for the considered period air velocity in the cell $l$; $\bar{\varphi}_{l}$ - average effective contaminant concentration for the cell $l$ (calculated in stage 1 ); $v_{l, k}^{\prime}=v_{l, k}-\bar{v}_{l}$ - particle $k$ velocity deviation from $\bar{v}_{l} ; v_{l, k^{-}}$ Lagrangian particle $\mathrm{k}$ velocity; $k$ - number of the Lagrangian particle passing through the considered plane in the computational cell $l ; \varphi_{l, k}^{\prime}=\varphi_{l, k}-\bar{\varphi}_{l}$ - concentration deviation at the back trajectory point $k$ from $\bar{\varphi}_{l}$.

\section{RESULTS OF THE HORIZONTAL FLUXES ESTIMATION}

The results of photometric measurements at the station of the global network AERONET [5], located on the territory of the Kourovo Astronomical Observatory near the city of Yekaterinburg, were used in the FLA simulation.

International Conference of Numerical Analysis and Applied Mathematics ICNAAM 2019

AIP Conf. Proc. 2293, 120014-1-120014-4; https://doi.org/10.1063/5.0026695

Published by AIP Publishing. 978-0-7354-4025-8/\$30.00 
The volume concentration of submicron aerosol $\left(\mu \mathrm{m}^{3} / \mathrm{cm}^{3}\right)$ was used as a characteristic of the aerosol content in the atmosphere. The volume concentration was calculated on the basis of the size distribution function of aerosol particles in an air column and an empirical model of the vertical profile of aerosol distribution for the region of Western Siberia [6].

The HYSPLIT software package [7-10] was used for calculation of back trajectories of air particles. The threedimensional back trajectories lasting 96 hours (four days) each, starting every hour at the location of the AERONET network monitoring point at 6 levels from 500 to $5500 \mathrm{~m}$ were calculated.

Calculations of the three-dimensional field of submicron aerosol concentrations for the regions of the Middle Urals and Western Siberia [11] were carried out in the geographical location $30^{\circ}-90^{\circ} \mathrm{E}$ and $50^{\circ}-70^{\circ} \mathrm{N}$. The height of the computational area was limited to $6 \mathrm{~km}$. The dimensions of the Eulerian cells were set $1^{\circ} \mathrm{x} 1^{\circ}$ horizontally, and $1000 \mathrm{~m}$ vertically. To precise the calculated source power field, the algorithm of the FLA method includes models considering the intensity of physical sinks of aerosol particles. Sinks due to two key mechanisms for removing impurities from the atmosphere - wet [12] and dry deposition of aerosol particles on the underlying surface [13] —were taken into account.

Figure 1 shows the total average effective field of the submicron aerosol volume concentration $\left(\mu \mathrm{m}^{3} / \mu \mathrm{m}^{2}\right)$. This field is the result of integration over the height of the aerosol concentration fields $\left(\mu \mathrm{m}^{3} / \mu \mathrm{m}^{3}\right)$. The star signs mark the AERONET network monitoring points in the Middle Urals, as well as in Moscow and Tomsk. Cross-hatched regions are areas lying outside the zone of influence on the monitoring stations considered here. In the given case, the influence zone was defined as a region of space in which the number of trajectories per calculation cell was greater than unity. In addition, the boundaries of states are shown, as well as the coastline of continents and islands.

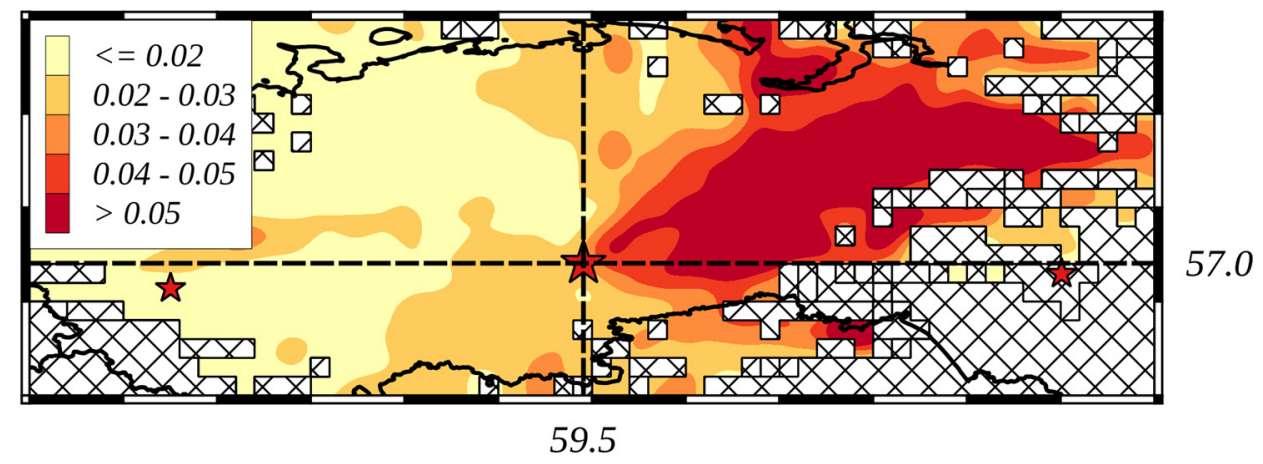

FIGURE 1. The average effective field of submicron aerosol volume concentration in $6 \mathrm{~km}$ column of the atmosphere $\left(\mu m^{3} / \mu m^{2}\right)$.

Horizontal fluxes were estimated through two planes drawn along the meridians and latitudes through the monitoring point (dashed lines in Fig. 1). Figures 2a and 3a show the vertical distributions of the average effective fields of submicron aerosol volume concentration in the meridional and latitudinal planes, respectively.

The results of estimates of meridional and latitudinal fluxes are shown in Fig. $2 b$ and $3 b$, respectively. The landscape is shaded in gray. A red triangle indicates the location of the measuring device. 


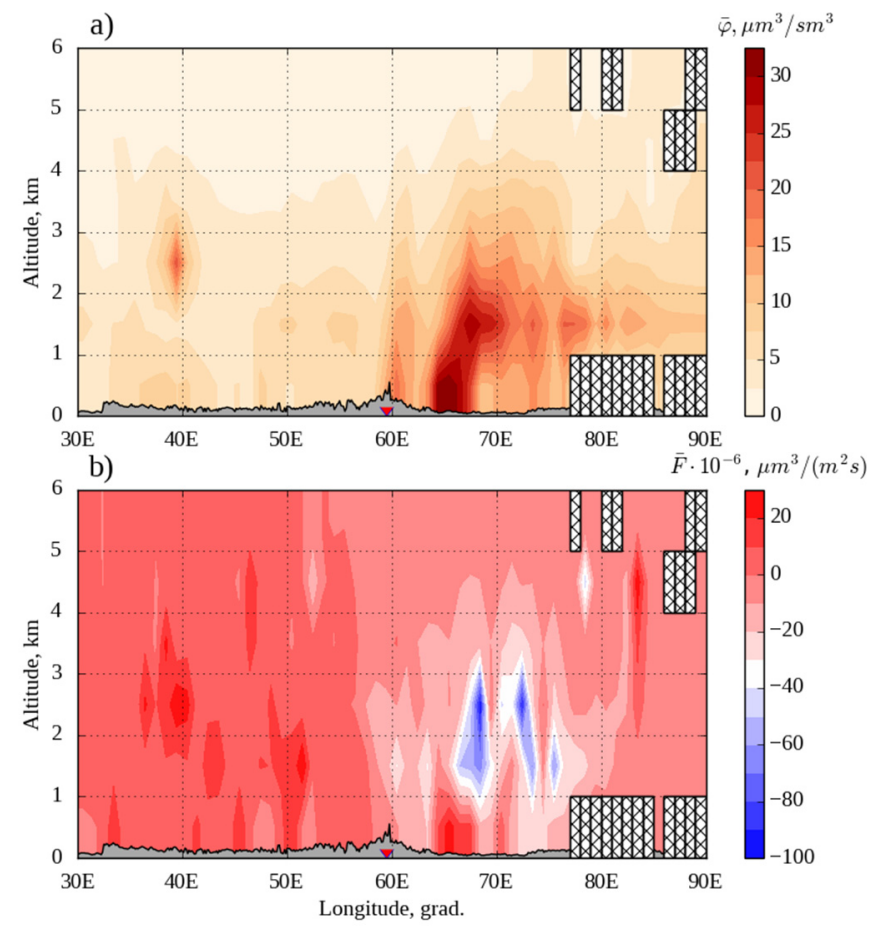

FIGURE 2. Assessment of the characteristics of a submicron aerosol in the Middle Urals in the meridional plane drawn through the monitoring station a) average effective concentrations calculated by the FLA method based on the results of photometric measurements in 2016; b) average fluxes calculated according to (1).

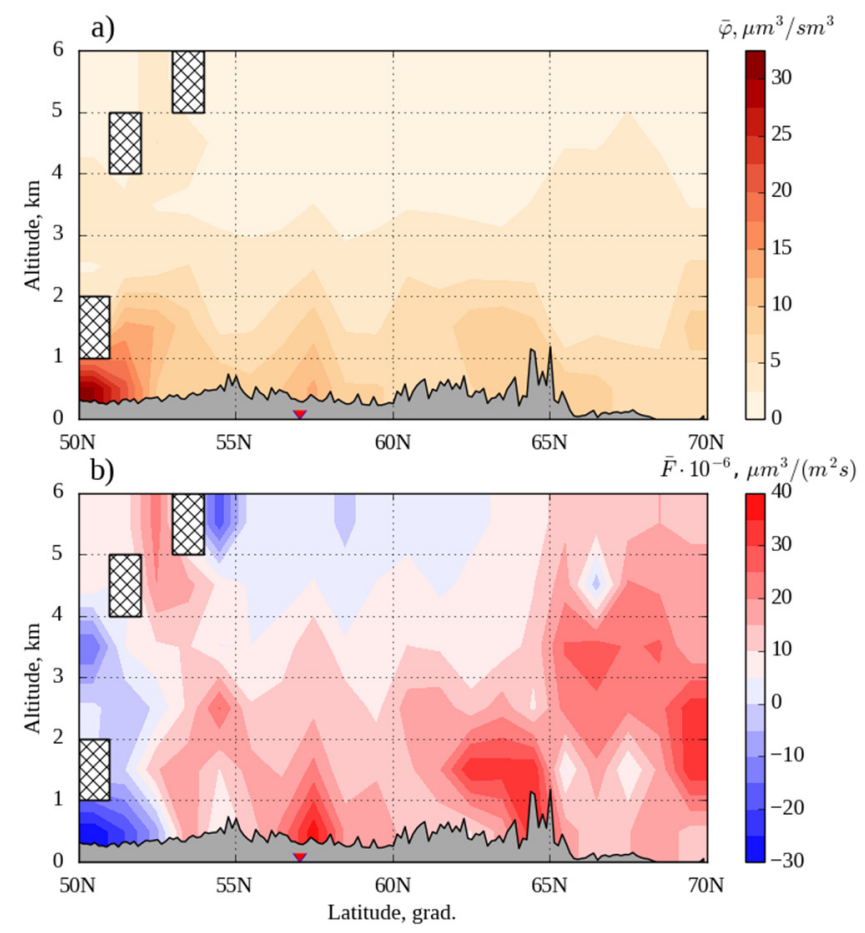

FIGURE 3. Assessment of the characteristics of a submicron aerosol in the Middle Urals in the latitudinal plane drawn through the monitoring station a) average effective concentrations calculated by the FLA method based on the results of photometric measurements in 2016; b) average flows calculated according to (1). 
Figure $2 \mathrm{~b}$ shows that the positive (directed from south to north) average flux of the submicron aerosol is realized in the region west of the monitoring point, while the eastern part is characterized by mostly negative (directed from north to south) aerosol fluxes. Large values of fluxes at altitudes of $1.5-2.5 \mathrm{~km}$ are probably the result of the transfer of smoke aerosols from the Siberian region in the summer of 2016.

As figure $3 \mathrm{~b}$ demonstrates, aerosol transfer was mainly carried out from west to east. Reverse transfer from east to west was observed for the southern part of the calculated plane.

It can be seen from the figure $2 b$ that in absolute terms maximum values were obtained for the meridional flux (about $100 \mu \mathrm{m}^{3} /\left(\mathrm{m}^{2} \mathrm{~s}\right)$ ). However such large values are characteristic only for localized small areas, while in the greater part of the plane the average fluxes mainly shows lower values (about $20 \mu \mathrm{m}^{3} /\left(\mathrm{m}^{2} \mathrm{~s}\right)$ ). Approximately the same lower values are typical for average latitudinal fluxes.

\section{ACKNOWLEDGMENTS}

The reported study was funded by RFBR according to the research project № 18-31-00170.

\section{REFERENCES}

[1] V.A. Poddubny and E.S. Nagovitsyna, "Retrieval of spatial field of atmospheric aerosol concentration according to data from local measurements: a modification of the method of back trajectory statistics", Izv. RAS, Physics of the atmosphere and ocean 49, 439-446 (2013).

[2] V.A. Poddubny and E.S. Dubinkina, "The problem of fluid location of the atmosphere for the estimation of pollution fields and retrieval of source", Optics of the atmosphere and the ocean (In Russian) 30, 862-870 (2017).

[3] E.S. Dubinkina and V.A. Poddubny, "Numerical implementation for the fluid location of atmosphere method", Mathematical simulation (In Russian) 30, 33-47 (2018).

[4] P. Seibert, H. Kromp-Kolb, U. Baltensperger, and et al., "Trajectory analysis of aerosol measurements at high alpine sites", Transport and Transformation of Pollutants in the Troposphere, 689-693 (1994).

[5] B.N. Holben, T.F. Eck, I. Slutsker, and et al., "Aeronet a federated instrument network and data archive for aerosol characterization", Remote Sens. Environ. 66, 1-16 (1998).

[6] Panchenko M.V., Kozlov V.S., Pol'kin V.V., and et al., "Retrieval of optical characteristics of the tropospheric aerosol in West Siberia on the basis of generalized empirical model taking into account absorption and hygroscopic properties of particles", Optics of the atmosphere and the ocean (In Russian) 25, 46-54 (2012).

[7] R.R. Draxler and G.D. Hess, "An overview of the hysplit-4 modeling system for trajectories, dispersion and deposition", Australian Meteorological Magazine 47, 295-308 (1998).

[8] V.A. Poddubny, E.S. Dubinkina, J.I. Markelov, A.G. Buevich, K.L. Antonov, E.V. Omelkova, I.L. Manzhurov, and A.N. Medvedev, "Recovery of average effective methane concentration field in the region of Kara and Barents Seas using a passive location of the atmosphere by wind", AIP Conference Proceedings 2040, 050020 (2018); https://doi.org/10.1063/1.5079118.

[9] Konstantin L. Antonov, Vassily A. Poddubny, Yury I. Markelov, Alexander G. Buevich, and Alexander N. Medvedev, "Dynamics of surface carbon dioxide and methane concentrations on the Arctic Belyy Island in 2015-2017 summertime", Proc. SPIE 10833, 24th International Symposium on Atmospheric and Ocean Optics: Atmospheric Physics, 108336H (13 December 2018).

[10] V.A. Poddubny, E.S. Dubinkina, J.I. Markelov, A.G. Buevich, K.L. Antonov, E.V. Omelkova, I.L. Manzhurov and A.N. Medvedev, "The Results of the Retrieval of Average Atmospheric Methane Fields from Summer Ground-Based Measurements on Bely Island in 2016 and 2017", AIP Conference Proceedings 2116, 200024 (2019); https://doi.org/10.1063/1.5114205.

[11] E.S. Dubinkina and V.A. Poddubny, "Simulation of three-dimensional submicron aerosol concentration fields based on the results of photometric measurements in the Middle Urals", Ecology. Economy. Informatics. Series: System analysis and modeling of economic and ecological systems (In Russian) 3, 26-30 (2018).

[12] H.N. Webster and D.J. Thomson, "The NAME Wet Deposition Scheme", Forecasting Research Division Technical Report No. 584, 43 (2014).

[13] L. Zhang, S. Gong, J. Padro, and et al., "A size-segregated particle dry deposition scheme for an atmospheric aerosol module", Atmos. Environ. 35, 549-560 (2001). 